\title{
COGNITIVE, PRAGMATIC AND INTERPRETATIVE DIMENSIONS OF NARRATIVE TEXTS IN CURRENT TRANSLATION STUDIES
}

Summary. The article discusses advantages of applying the interpretative approach in translation of literary
texts that evolved on the premise of research findings in cognitive linguistics and pragmatics. The author claims
it to be crucial to study the impact that the cultural context of the source text makes on translation and the tar-
get text in terms of its cognitive-pragmatic structuring in the process. The paper also aims to give an overview of
the major cognition-related issues and to outline the main challenges of literary text translation with the focus
on a number of linguistic and culture specific factors within an interpretative framework. The author highlights
the significance of deepening further theoretical postulates worked out in current translation studies to research
diverse means and ways, involved in the reconstruction of the source text message in the target text by a system
of carefully chosen linguistic means, to convey semantics and pragmatics of the text properly. It is maintained
that translation procedure encompasses the study of particularities of knowledge structures, verbalized in the
text, as well as consideration of text social, cultural, and conceptual dimensions. The world models, present in
the text continuum, manifest different features, so, the use of certain linguistic devices as well as the interpre-
tation and transference of the narrative content, of its special pragmatic and semantic features should be based
on the theoretical postulates of cognitive translatology to ensure adequate translation choices.

Keywords: translation process, interpretative approach, cognitive dimension, cultural dimension, world model, text continuum, knowledge structure.

Чугу С.Д.

Вінницький торговельно-економічний інститут Київського національного торговельно-економічного університету

\section{КОГНІТИВНО-ПРАГМАТИЧНИЙ І ІНТЕРПРЕТАТИВНИЙ ВИМІРИ ПЕРЕКЛАДУ ХУДОЖНЬОГО ПРОЗОВОГО ТЕКСТУ У СУЧАСНІЙ ТРАНСЛЯТОЛОГІЇ}

Анотація. У статті доводиться необхідність використання новітніх дослідницьких підходів, розроблених у межах когнітивно-прагматичної парадигми, обгрунтовуеться важливість застосування інтерпретативного підходу до перекладу художнього тексту, підкреслюеться аксіоматичність теоретико-методологічних постулатів, що віддзеркалюють притаманні міждисциплінарній парадигмі наукових знань, зокрема у галузі теорії комунікації, когнітивістики, культурології, прагматики та психології. Загальна спрямованість сучасних лінгвістичних студій на вивчення особливостей взаємодії мови і мислення, мови і культури зумовлюе необхідність урахування в транслятологічних наукових розвідках закономірностей конструювання $\mathrm{i}$ реконструювання ментальних конструктів у ході перекладу тексту для вибору вірних інтерпретаційних інструментів та досягнення правильного тлумачення змісту повідомлення. Автор наголошуе на необхідності вивчення особливостей репрезентації структурованих знань в художній моделі світу та аналізуе особливості текстової репрезентації знань у єдності мовного та концептуального аспектів, досліджує прагматичне навантаження мовних засобів у межах когнітивно-прагматичного підходу з урахуванням результатів міждисциплінарних студій, пояснюючи, що актуальність подальшої розробки інтерпретативного підходу до перекладу художнього тексту зумовлена необхідністю поглиблення розуміння складних механізмів кодування та декодування змістового наповнення тексту, в художньому просторі якого моделюються декілька альтернативних конструктів світу з певними соціокультурними ознаками. Вивчення лінгвістичних засобів вербалізації концептуального виміру тексту уможливлюе встановлення їх прагматичного навантаження та дослідження впливу семантики окремих мовних елементів на способи представлення знань у текстовому просторі, з огляду на твердження, що концептуально-комунікативний вимір художнього тексту є джерелом об'єктивованих у текстовому просторі структур знань. Інтерпретативний підхід до перекладу тексту забезпечує його адекватне розуміння завдяки комплексному сприйняттю інформації, закладеної у системі концептуалізованих дій, подій та процесів, що локалізовані у просторово-часових рамках текстового простору та у багатошаровій абстрактній моделі уявного світу. 3 огляду на динамізм процесів у транслятології перспективу подальшого вивчення когнітивно-прагматичних характеристик художнього тексту вбачаємо у дослідженні його полімодальності та розкритті семантичного потенціалу лінгвістичних засобів, що вербалізують концептуальні структури і формати знань, наявні у художній моделі світу.

Ключові слова: процес перекладу, інтерпретативний підхід, когнітивний вимір, культурний аспект, модель світу, текстовий простір, репрезентація знань.

$\mathrm{P}$ roblem statement. Current translation studies, due to pivotal advances in the cognitive-pragmatic paradigm, focus on multifaceted and solid study of various perspectives, dealing with the interpretation of linguistic expressions in discourse and text. These are grounded on the theoretical as- sumptions and factual findings that outline new trends in the study of cognitive, communicative and socio-cultural aspects of linguistic meanings. Translation studies as a separate branch in translation have taken a new turn in the mid-nineties when the necessity to deepen the understanding of linguistic 
nature of translations of diverse genre texts in different social contexts in terms of determining basic correlations between source and target messages was recognized as a priority in translatology. A number of hypotheses, put forward in the works by M. Baker, B. Comrie, G. Hansen, O. Rebrii on fundamental features of translation, translation universals, disambiguation, simplification, explicitation being the most important ones, caused large-scale discussions and, subsequently, shaped current translation studies paradigm $[2 ; 4 ; 7 ; 11]$.

Recent research and publications. The major premise of the current translation studies lies on the theoretical generalizations worked out in the seminal works by A. Pym, G. Toury, M. Tomasello $[8 ; 11 ; 12]$. Irrespective of numerous research of culture in translation, a number of translation challenges caused by the issues related to the intricate and elaborate relations between culture and translation in terms of the nature and transfer of meanings in particular situational contexts of interpretation call for the integrated approach that will combine findings from research in social and linguistic sciences to address the problems of adequacy and equivalence between source and target texts. As S. Chugu emphasizes, translation procedure encompasses the analysis of particularities of knowledge structures, verbalized in the text, as well as consideration of text social, cultural and conceptual dimensions, the use of certain linguistic devices as well as the interpretation and transference of the narrative content, of the special features of its pragmatics and semantics should be based on the theoretical postulates of cognitive translatology to ensure adequate translation choices $[1 ; 3]$.

Given the importance of the research of multifaceted means and ways involved in the reconstruction of the source text message in the target text by a system of carefully chosen linguistic means to convey semantics and pragmatics of the text properly, the article will focus on the particularities of the interpretative approach to the transfer of the overall meaning and message of the source text to make sure that its fundamental features are translated adequately to convey the meanings accurately enough to ensure the semantics and pragmatics are perceived in a proper way in the target socio-cultural context. Thus, the purpose of the article is to focus on providing insights into the interpretative approach to translation and to outline effective ways to enforce the overall quality of meaning transition of the source message into a target one in terms of its conceptual, pragmatic, and communicative equivalence.

Presentation of the main material. A substantial overview of current translation theories by A. Pym focuses on the translation in terms of equivalence; still the transfer of the source text particularities into the target texts is to fit the socio-cultural models in the target culture in accordance with inter-lingual, intra-lingual, and inter-semiotic modes [8]. The main translation challenges are caused by the complexity and variety of the ways of transferring figurative language means, which necessitate further research to understand interrelations between culture, language, and thought [10;13].

The interpretative approach offers new insights into transfer of culture in translation providing ar- guments for relevant interpretation of the source text in the process of translation is possible only if proper decoding of meanings is well-grounded in the conceptual and socio-cultural characteristics related to conceptual events, situations, and knowledge structures. Undoubtedly, the main translation principles used in the transfer of culture specific information call for the use of special techniques based on the assumption of the impact of cultural differences on translation process.

In our belief, translatological analysis of literary text excerpts, grounded on the study of meaning $[5 ; 6]$, proves the necessity to apply an integrated interpretative approach to the translation of the source text into the target one so that to reveal the most important concepts and knowledge formats, imbedded' in its conceptual dimension and represented in special ways in the surface structure via a complex system of carefully chosen linguistic devices to convey the text message. Let us look into the features of the text extracts that are to be decoded carefully before getting down to translating them.

$<\ldots>$ There's an open box to drop coins in, if you want to. I pay up and drive into the grounds, where I find two castles for the price of one.

Puxley's Castle is a nineteenth-century Romanesque mansion, all Gothic arched windows and marble-clad pillars. It was built by the Puxley family, who made their millions in copper mining, or at least in owning the mines in which other people went mining. Their colourful family history, with little altered except the names, is told in Daphne du Maurier's novel Hungry Hill. From the point the castle there's a glorious view across a tidal channel to the real Hungry Hill, which looms high behind Castletownbere.

Inside, chunks of stone and marble litter the ground. The roof's gone. Shrubs and wild flowers are growing in impossibly high places. Some rooms are thick with hoof prints and cowpats. It was burned and gutted by the IRA during the Civil War in 1921 [MP, p. 135-136].

The sarcasm conveyed by the implications of the phrase Puxley's Castle is a nineteenth-century Romanesque mansion with the hints on the vanity of the family making their mansion in the Romanesque style ironically in the XIX century and naming it using the grand idea of Puxley's Castle in combination with their family name, intensified by the use of the lexeme all in the initial position of the phrase Gothic arched windows and marble-clad pillars.

The use of the references to the literature and culture specific notions Daphne du Maurier's novel Hungry Hill calls for the analysis of the cultural dimension of the text in the translation process. It appears that the particularities of the conceptual aspect are to be considered seriously with the name of the location Hungry Hill being significant for the understanding of the local history and its impact on the conventions, traditions, and the general world view of the inhabitants of Castletownbere, who used to be employed in copper mining and actually made millions for the Puxleys. Still another perspective of analysis is to address the information of social and historical significance of the notions such as the IRA and the Civil War in 1921. These need special explanations for readers to interpret the historical events (the Civil War and the organization IRA) correctly. 
The way, the other of the two castles is described, reveals the cruelty, violence, and evil of war times and historical events that took place in Castletownbere: A few hundred yards away, facing Bere Island across the channel into Castletownbere harbor, is Dunboy Castle, the rugged stone ruin of a thirteenth century fortress. After the English hammered the combined Irish and Spanish forces at the Battle of Kinsale in 1602, this was the next target. The entire garrison of $\mathbf{1 4 3}$ men was slaughtered, including - and some people are still a bit miffed about this, even 400 years later - the priest who walked out carrying the white flag. There are plaques to him in Irish and in English. I sit on the mossy remains of a wall that was destroyed while Shakespeare was writing Hamlet, and contemplate this landscape that for centuries was the stronghold of the O'Sullivans. Before them the ruling clan here had been McCarthys [MP, p. 136].

The dramatic history of the place is presented via a number of linguistic devices, which pragmatic effect makes the description vivid and impressive: the English hammered the combined Irish and Spanish forces at the Battle of Kinsale in 1602. The entire garrison of 143 men was slaughtered, including $<\ldots>$ the priest who walked out carrying the white flag. There are other important references that are to be interpreted correctly to decode the message and some people are still a bit miffed about this, even 400 years later; while Shakespeare was writing Hamlet; that for centuries was the stronghold of the O'Sullivans; Before them the ruling clan here had been McCarthys.

Translatological analysis of the excerpts reveals the necessity of accurate application of multistep algorithm procedure that ultimately includes proper identifying of the text message, analyzing language devices of the source text and transferring it adequately into target cultural context via a care- fully chosen linguistic means. The approach proves effective due to the fact that it recognizes the importance of basic cognitive issues as the fundamental conceptual basis for language expressive means, thus, putting emphasis on the proper choices of linguistic devices in the translation process to ensure appropriate translation decisions.

Conclusion. As universal meaning structures, enriched by culturally specific patterns of conceptual integration, make a huge layer of text continuum it is instrumental to consider these ethno-cultural particularities in a logical and sustainable manner from cognitive and pragmatic perspectives. The vital role of cognitive translatology that resulted in designing the interpretative approach in translation studies focuses on the study of the ways meanings are construed at different levels in the target text.

The interpretative approach has become a beneficial asset to current translation studies, as it is based on the clear understanding of the role of adequate interpretation of conceptual constructs and knowledge formats objectivized in the semantic and pragmatic dimensions of the text. Interpretative translation considers diverse meanings and functions of the language units providing insights into mechanisms of linguistic categories representation of conceptual categories through a complex combination of lexical and grammatical devices that pattern culturally specific meanings in discourse and text.

The interpretative algorithm provides proper ways and tools to ensure adequate transfer of culture specific notions in decoding and coding of meanings in accordance with language conventions, so it proves essential for a successful intercultural transfer. The study of the interpretative approach potential outlines the prospect of polishing research design to ensure reliable results and logical conclusions that might prove effective in translation theories and practices.

\section{References:}

1. Chugu S.D. Kontseptual'nyy vymir khudozhn'oho tekstu u interpretatyvniy paradyhmi [Interpretative Perspective of the Literary Text Cognitive Dimension]. Bulletin of Mariupol State University Series: Philology. 2017. Vol. 17. P. 93-88.

2. Baker M. In Other Words: A Coursebook on Translation. 2-nd edition. Routledge, 2011. 352 p.

3. Chugu S. Formulaic language sequences in discourse and narrative: constructionist approach. Zhytomir Ivan Franko State University Journal. 2017. Vol. 1(85). P. 10-14.

4. Comrie B. On explaining language universals. The New Psychology of Language / Ed. M. Tomasello. Mahwah, NJ: Lawrence Erlbaum, 2003. Vol. 2. P. 195-209.

5. Coulson S., Todd O. Blending and coded meaning: Literal and figurative meaning in cognitive semantics. Journal of Pragmatics. 2005. Vol. 37. P. 1510-1536.

6. Doloughan F. J. Contemporary Narrative: Textual Production, Multimodality and Multiliteracies. London: Continuum, 2011. 168 p.

7. Hansen G. Success in translation. Perspectives. Studies in Translatology, 2010. Vol. 5(2). P. 201-210.

8. Pym A. Exploring Translation Theories. $2^{\text {nd }}$ edition. London: Routledge, 2014. 192 p.

9. Rebrii O. Systemic Approach to Translation: Experimental Research. Advanced Education. 2017. Vol. 8. P. 109-114.

10. Tkachuk T. Realia types and strategies of their translation in frames of cultural translation. International Humanitarian University Herald. Philology. Odessa. 2017. Vol. 2. Issue 30. P. 105-107.

11. Tomasello M. Origins of Human Communication. Cambridge: The MIT Press, 2008. 345 p.

12. Toury G. Probabilistic Explanations in Translation Studies: Universals - Or a Challenge to the Very Concept? Translation universals : Do they exist? Amsterdam, Philadelphia: John Benjamins, 2004. V. 48. P. $15-32$.

13. Translation universals: Do they exist? / Eds. A. Mauranen, P. Kujamäki. Amsterdam, Philadelphia: John Benjamins, 2004. V. 48. 418 p.

\section{List of illustration materials:}

1. McCarthy P. McCarthy's Bar. A Journey of Discovery in Ireland. Hodder \& Stoughton: SCEPTRE, 2000. 374 p. 


\section{Список літератури:}

1. Чугу С.Д. Концептуальний вимір художнього тексту у інтерпретативній парадигмі. Вісник Маріупольського державного університету. Серія : Філологія. Маріуполь, 2017. Вип. 17. С. 93-98.

2. Baker M. In Other Words: A Coursebook on Translation. 2-nd edition. Routledge, 2011. $352 \mathrm{p}$.

3. Chugu S. Formulaic language sequences in discourse and narrative: constructionist approach. Zhytomir Ivan Franko State University Journal. 2017. Vol. 1(85). P. 10-14.

4. Comrie B. On explaining language universals. The New Psychology of Language / Ed. M. Tomasello. Mahwah, NJ : Lawrence Erlbaum, 2003. Vol. 2. P. 195-209.

5. Coulson S., Todd O. Blending and coded meaning: Literal and figurative meaning in cognitive semantics. Journal of Pragmatics. 2005. Vol. 37. P. 1510-1536.

6. Doloughan F.J. Contemporary Narrative: Textual Production, Multimodality and Multiliteracies. London : Continuum, 2011. 168 p.

7. Hansen G. Success in translation. Perspectives. Studies in Translatology, 2010. Vol. 5(2). P. 201-210.

8. Pym A. Exploring Translation Theories. $2^{\text {nd }}$ edition. London : Routledge, 2014. $192 \mathrm{p}$.

9. Rebrii O. Systemic Approach to Translation: Experimental Research. Advanced Education. 2017. Vol. 8. P. $109-114$.

10. Tkachuk T. Realia types and strategies of their translation in frames of cultural translation. International Humanitarian University Herald. Philology. Odessa, 2017. Vol. 2. Issue 30. P. 105-107.

11. Tomasello M. Origins of Human Communication. Cambridge : The MIT Press, 2008. 345 p.

12. Toury G. Probabilistic Explanations in Translation Studies: Universals - Or a Challenge to the Very Concept? Translation universals : Do they exist? Amsterdam, Philadelphia : John Benjamins, 2004. V. 48. P. 15-32.

13. Translation universals: Do they exist? / Eds. A. Mauranen, P. Kujamäki. Amsterdam, Philadelphia : John Benjamins, 2004. V. 48. 418 p.

\section{Список джерел ілюстративного матеріалу:}

1. McCarthy P. McCarthy's Bar. A Journey of Discovery in Ireland. Hodder \& Stoughton: SCEPTRE, 2000.374 p. 